УДК 355.124.4/.5:94(47).084.8“1944”)

КРИВИЗЮК Л. П.

https://orcid.org/0000-0001-9094-4061

https://doi.org/10.33577/2313-5603.35.2021.170-192

\title{
БІЛОРУСЬКА СТРАТЕГІЧНА НАСТУПАЛЬНА ОПЕРАЦЯ (23 ЧЕРВНЯ - 29 СЕРПНЯ 1944 РОКУ): ОРГАНІЗАЦІЯ ВЗАЕМОДІЇ ВІЙСЬК ЧОТИРЬОХ ФРОНТІВ
}

Аналізується Білоруська стратегічна наступальна операція: обстановка, що склалася на території Білорусії після бойових дій взимку і весною 1944 р.; загальні плани сторін на літньо-осінню кампанію; замисли командувачів фронтів на проведення фронтових операцій і завдання військам; питання взаємодії військ фронтів, загальновійськових армій, рухомих груп, артилерійських i авіаційних з'єднань в ході підготовки та проведення операції і зроблено висновки.

Ключові слова: Білоруська стратегічна наступальна операція, Ставка ВГК, фронт, армія, корпус, противник.

Постановка проблеми. В результаті успішно проведених наступальних операцій Червона Армія (ЧА) розгромила сильні стратегічні угруповання військ вермахту, створила сприятливі умови для ліквідації центрального угруповання, що діяло на території Білорусії. Білоруський виступ утворився в результаті розгрому північного угруповання вермахту під Ленінградом і Новгородом та південній - на Правобережній Країні взимку і весною 1944 р. (Воробьев, Кравиов, 1953: 299). Північний кінець виступу спирався на Полоцьк і Вітебськ, а південний - на басейн річки Прип'ять. Необхідно було ліквідувати виступ, щоб виключити можливість флангового удару вермахту.

Враховуючи обстановку, що склалася на німецько-радянському фронті до кінця травня 1944 року, Ставка Верховного Головнокомандування (ВГК) на літньо-осінню кампанію планувала підготувати і провести низку стратегічних наступальних операцій на всьому німецько-радянському фронті.

Щоб скрити від німецького командування, що саме в Білорусії ЧА завдає головний удар, планувалося військами 1-го Українського фронту (УФ) (Кривизюк, 2010: 49-63) завдати потужний удар на

Кривизюк Леонід Петрович, кандидат історичних наук, доцент, заступник завідувача кафедри військової підготовки Національної академї сухопутних військ імені гетьмана Петра Сагайдачного, м. Львів

(C) Кривизюк Л.П., 2021 
львівському напрямку, а після решту фронтами - на інших стратегічних напрямках (Жилин, 1986: 241).

Підготовку до наступних операцій здійснювало і ВГК вермахту. Але під час оцінки можливих дій ЧА припустилося помилки, передбачаючи, що основні події розгорнуться не на центральному, а на південно-західному напрямку. Допущеним промахом логічно скористалися Ставка ВГК і Генеральний штаб (ГШ) ЧА (Дайнес, 2009: 477-478).

До угруповання військ ЧА на 1 червня входило вісімнадцять загальновійськових, 1-ша армія Війська Польського і п’ять повітряних армій (стрілецьких дивізій $(c \partial)-146$, стрілецьких бригад (сбр) - 2 і укріплених районів (УР) - 7, $m \kappa-3, м \kappa-1, \kappa \kappa-$ 2 тощо) (Жилин, 1988: 160-165).

Проведення операції поділялося на два етапи 3 проведення фронтових наступальних операцій. Перший етап (23 червня4 липня): Вітебсько-Оршанська, Могильовська, Бобруйська, Полоцька i Мінська. Другий етап (5 липня - 29 серпня): Вільнюська, Шяуляйська, Білостоцька, Люблін-Берестейська, Каунаська.

Аналіз попередніх досліджень $i$ публікацій. Білоруська стратегічна наступальна операція збагатила теорію та практику воєнного мистецтва новими прийомами і способами збройної боротьби, про що свідчить історіографія Другої світової війни, яка налічує численні джерела i наукові праці, мемуарну та популярну літературу. Однією з найчисельніших історіографій 3 розкриття операції «Багратіон» є радянська (Лотоцкий, 1970; Платонов, 1958; Поспелов, 1962; Ротмистров, 1963; Семиряга, 1978; Строков, 1966; Жилин, 1988; Тельпуховский, 1959), яка розкриває загальний характер підготовки і проведення операції. Операція «Багратіон» у радянській історіографії розглядається як найвидатніша стратегічна операція за весь 1944 р. Належне місце відведене і танковим військам (Советские ТВ 1941-1945, 1973), де досліджується роль і місце радянських танкових військ у найбільших битвах Другої світової війни, аналізуються способи ведення бойових дій танкових військ, особливо заслуговують уваги праці безпосередніх учасників тих подій, і насамперед, командувачів танкових армій А.П. Ротмістрова (5 гв. ТА) (Ротмистров, 1972) і А.І. Радзієвського (2 ТА) (Радзиевский, 1977), які основну увагу приділяють ролі радянських танків, узагальнюють досвід бойового застосування танкових армій у 
наступальних операціях під час Другої світової війни і мистецтву управління танковими військами.

Поважне місце в комплексі джерел дослідження розвитку воєнного мистецтва в Білоруській операції належить мемуарас від обох воюючих сторін, особливо твори визначних воєначальників, за безпосереднього керівництва яких готувалась i проходила операція «Багратіон». Передусім це спогади представників Ставки ВГК, яким було доручено координувати діяльність трьох білоруських і 1-го Прибалтійського фронтів, маршалів Радянського Союзу А. М. Василевського і Г. К. Жукова (Василевский, 1978; Жуков, 1983), командувачів 1 БФ К. Рокоссовского (Рокоссовский, 1988) і 1 ПФ І. Баграмяна (Баграмян, 1977), а також начальника Оперативного управління Генштабу С. Штеменко (Штеменко, 1975), який брав безносередню участь у розробці плану операції. 3 німецької сторони Вернера Хапта, колишнього офіцера вермахту (Хаупm, 2006), який на основі документів і спогадів очевидців коротко і змістовно описує хід бойових дій групи армій «Центр» і командувача 4 А вермахту Курта фон Тіппельскірха (Типпельскирх, 1999), який оцінює діяльність державних i військових керівників протиборчих сторін.

Сучасна історіографія в дослідженні питань радянського воєнного мистецтва та власне операції «Багратіон» характерна критичним аналізом, якому піддається радянська воєнна стратегія та оперативне мистецтво і грунтується на документальній базі (Дайнес, 2009; Дайнес, 2010; Бешанов, 2005; Кривошеев, 1993; Операиия «Багратион», 2004; Исаев, 2014).

Особливу цінність для дослідження воєнного мистецтва щодо взаємодії військ у Білоруській стратегічній наступальній операції мають архівні матеріали (Русский архив, 1999; ЦАМО РФ).

Mema cmammi. Дослідити організацію управління Ставки ВГК, Генерального штабу у взаємодії зі штабами фронтів в Білоруській стратегічній наступальній операції та їх внесок у розвиток оперативного мистецтва 3 теорії і практики оточення та знищення крупних угруповань противника, як у складі групи фронтів, так і одного фронту.

Виклад основного матеріалу. Звільнення більшої частини Білорусії планувалося ще під час зимово-весняного наступу ЧА, коли радянські війська повинні були вийти на лінію Лепель, 
Мінськ, Брест. Але залучення величезних сил для здійснення наступальних операцій на Україні і на центральному напрямку не дозволило ВГК ЧА здійснити плани (Бешанов, 2005: 404).

До літа 1944 р. німецьким командуванням на території Білорусії було створено сильну багатосмугову i глибокоешелоновану оборону. Тактична зона оборони складалася 3 двох смуг на глибину 8-12 км. За тактичною зоною оборони розташовувалися чотири основні і декілька проміжних смуг,шо проходили зазвичай берегами річок Дніпро, Друть, Березіна. А міста Вітебськ, Орша, Могильов, Жлобін, Борисов, Бобруйськ були сильно укріплені. Глибина оборони угруповання німецьких військ у Білорусії досягала 250 - 270 км (Строков, 1966: 445).

До проведення операції командування ЧА долучало війська 1-го Прибалтійського фронту (1 ПФ) (командувач - генерал армії I.X. Баграмян), 3-го Білоруського фронту (БФ) (командувач генерал-полковник, з 26.06.1944 генерал армії І.Д. Черняховський), 2 БФ (командувач - генерал-полковник, 3 28.07.1944 - генерал армії І.Ф. Захаров) і 1 БФ (командувач - генерал армії, 3 28.07.1944 - Маршал Радянського Союзу К.К. Рокоссовський), Дніпровської військової флотилії (командувач - капітан першого рангу В.В. Григор'єв) ((Лотоикий, 1970: 267).

Перед військами ЧА на 1 100-км фронті оборонялося крупне угруповання противника групи армій «Центр» (командувач генерал-фельдмаршал Е. фон Буш, 328 червня - генералфельдмаршал В. Модель). До складу угруповання входили: 3 танкова армія (ТА), 4 армія (А), 9 А, 2 А, а також частина сил 16 A і 4 TA із груп армій «Північ» і «Північна Україна», всього 63 дивізії і 3 бригади. Загальна чисельність гітлерівських військ у Білорусії сягала понад 1200 чол. (з урахуванням тилів), понад 9,5 тис гармат і мінометів, 900 танків і штурмових гармат, 1350 літаків (Строков, 1966: 445).

Лінію оборони в Білорусії німецьке ВГК назвало «Фатерланд» («Вітчизна»), підкресливши тим самим, що, борючись тут, німецька армія нібито захищає свою батьківщину (Поспелов, 1962: 156).

До початку підготовки наступу у смузі від оз. Нещердо до Верба війська ЧА охоплювали головні сили противника. В тилу угруповання військ вермахту вели активні дії великі сили радянських партизан. 
Війська 1 ПФ (4-та ударна (УА), 6-та гвардійська (гв. А) армії, 43 А і 3 ПА) займали оборону на фронті протяжністю близько 160 км по лінії оз. Нещердо, Сиротино, на північ від Вітебська до Зах. Двіни, охоплюючи лівим крилом фронту угруповання противника, що діяло в районі Вітебська.

Війська 3 БФ (39 А, 5 А, 11 гв. А, 31 А і 1 ПА) обороняли рубіж на 130-км фронті і прикривали смоленський напрямок, а правим крилом охоплювали 3 південного сходу угруповання противника, що оборонялося в районі Вітебська. 11 гв. А, що прибула з резерву Ставки ВГК, знаходилася в резерві фронту.

Війська 2 БФ (33 А, 49 А, 50 А і 4 ПА) займали оборону на фронті протяжністю 160 км, прикриваючи рославльський напрямок.

Війська 1 БФ обороняли рубіж по р. Друть від Хомичі до Рогачова, далі по р. Дніпро до Жлобина, гирло р. Птич, по правому березі р. Прип'ять до Ратно, на схід від Ковеля, Верба. Протяжність лінії фронту досягала 700 км.

Праве крило 1 БФ (3 A, 48 А, 65 А, 28 А, 1-й механізований (мк), 4-й гв. кавалерійський (кк) і 9-й танковий (тк) корпуси, Дніпровська військова флотилія), діючи на північ від р. Прип’ять, займало вигідне оперативне становище стосовно противника, який оборонявся в районі Бобруйська, охоплюючи його військами 65 A і 28 А $з$ південного сходу. На південь від р. Прип'ять від Багримовичи до Ратно, на 360-км фронті діяли війська 61 А.

На південь від Ратно до розмежувальної лінії з 1 УФ займали рубіж оборони 70 A, 47 А і 69 А лівого крила 1 БФ, за ними розташовувалися основні резерви фронту (1-ша Польська армія, 8 гв. $т к, 11$ тк, 7 гв. кк тощо) (Платонов, 1958: 283-284).

Планування і підготовка Білоруської операції почалося наприкінці березня-квітні 1944 р. 22-23 травня. В Ставці ВГК за участю командувачів фронтами відбулося всебічне обговорення їі плану, а 30 травня він був затверджений. Мета операції полягала в розгромі групи армій «Центр», звільнення Білорусії, відновленні західного державного кордону і перенесення бойових дій на територію Польщі.

Відповідно до цього плану 31 травня фронтам (2 БФ, 1 БФ, 1 ПФ, 3 БФ) було поставлено завдання (Директиви Ставки ВГК №№ 220 112, 220 113, 220 114, 220 115) на перший етап операції (Русский архив, 1999: 93-95). «Тривала і ретельна підготовка операції, проведена Ставкою і Генеральним штабом в тісній 
співдружності з командуванням фронтом і їх штабами, повністю себе виправдала» (Штеменко, 1975: 330).

Конкретні завдання фронтам були визначені до рубежу Лепель, p. Березина, Слуцьк (на глибину до 160 км). Після їх виконання передбачалося подальші завдання уточнити 3 врахуванням обстановки, що складеться (Лотоикий,, 1970: 266).

Для координації дій фронтів Ставка ВГК виділила своїх представників: 1 ПФ і 3 БФ - Маршала Радянського Союзу А. М. Василевського, 2 БФ і 1 БФ - Маршала Радянського Союзу Г. К. Жукова (Поспелов, 1962: 161).

Всі підготовчі заходи проводилися в суворій таємниці. Щоб приховати терміни початку операції, Ставка ВГК наказала військам 3 ПФ, 2 ПФ і 1 УФ на північ і південь Білорусії 2223 червня провести розвідку боєм, а командувачу авіації дальньої дії - зосередити більшість своїх з'єднань на захід і південний захід від Києва. Напередодні операції проводились заходи 3 дезінформації противника. Зокрема, на правому крилі 3 УФ фронту імітувалося зосередження 8-10 стрілецьких дивізій, посилених танками і артилерією тощо (Русский архив, 1999: 14). В 1 БФ демонструвалося відведення військ і техніки 3 плацдармів. Армійські і фронтові газети розміщували статті про необхідність посилення оборони. Із залізничних станцій, що розташовувалися поблизу плацдармів, у східному напрямку відправлялися макети танків і артилерії. На лівому фланзі 1 УФ здійснювалося хибне зосередження двох танкових армій (Лотоцкий, 1970: 306). До планування операції було допущено обжене коло осіб. Арміям i дивізіям віддавалися часткові директиви i накази, в яких детально доводилися завдання військ і надавалася коротка інформація щодо завдань сусідів. Бойові документи розсилалися за декілька днів до початку наступу.

Питання взаємодії загальновійськових армій, рухомих груп i авіаційних з'єднань відпрацьовувалися на всю глибину операції методом проведення оперативних ігор на картах.

Взаємодія між родами військ при прориві тактичної зони оборони противника відпрацьовувалися на ящиках з піском або на крупномасштабних планах. Заняття зазвичай проводили командувачі армій (Платонов, 1958: 320).

У здійсненні замислу операції вирішального значення набуває швидкість і стрімкий наступ. Тому танкові армії, окремі танкові і 
механізовані корпуси використовувалися для розвитку успіху i стрімкого наступу вглибину оборони противника 3 метою розсічення та оточення військ противника. Ешелон розвитку успіху 1 ПФ було визначено 1 к (командир - генерал-лейтенант т/в В.В. Бутков), а в 11 гв. А 3 БФ - 2 гв. $m \kappa$ (командир - генералмайор т/в О.С. Бурдейний). Розвиток успіху 3 А і 65 А 1 БФ покладався на $9 m \kappa$ (командир - генерал-майор т/в Б.С. Бахаров, 3 17.07.1944 - генерал-майор т/в M.І. Воєйков) і 1 гв. (командир - генерал-лейтенант т/в М.Ф. Панов) відповідно. 3 гв. мк (командир - генерал-лейтенант т/в В.Т. Обухов) 3 БФ і 1 мк (командир - генерал-лейтенант т/в С.М. Кривошеїн) 1 БФ входили до складу кінно-механізованих груп (КМГ). 5 гв. ТА (командувач - маршал бронетанкових військ П.А. Ротмістров, 3 8.08. по 18.08.1944 р. - генерал-лейтенант т/в М.Д. Соломатін, 3 18.08.1944 p. - генерал-лейтенант т/в В.Т. Вольський) була визначена для розвитку успіху 3 БФ (Дайнес, 2009: 479-480).

Вітебсько-Оршанська операчія військ 1 ПФ і 3 БФ, розпочалася вранці 22 червня проведенням розвідки боєм силами передових загонів. На ділянках 6 гв. А і 5 А 3 долученням частини сил дивізій першого ешелону вони просунулися на 6-7 км, а місцями подолали головну смугу оборони противника. На оршанському напрямку розвідка встановила, що оборона міцно утримується ворогом, тому внесено деякі уточнення до вогневого ураження противника і вранці 23 червня після артилерійської і авіаційної підготовки в наступ перейшли головні сили фронтів.

Командир 5 гв. ск, використавши танкові десанти, захопив три справні мости на р. Лучеса i до 12 год. основні сили корпусу подолали річку, а до кінця дня просунулися на глибину до 13-14 км. Е. фон Буш увечері того ж дня визнавав, що потужний наступ на північний захід від Вітебська означав повну несподіванку, так як до цього часу ми не припускали, що противник міг зосередити перед нами такі великі сили (Xaynm, 2006: 310).

Використовуючи успіх ударне угруповання 1 ПФ на другий день операції просунулося на 36 - 38 км, вийшовши до Зах. Двіни i 3 ходу захопили ряд плацдармів. 25 червня угруповання противника у складі п'яти дивізій було оточено і розчленовано на дві частини: одна блокована у Вітебську, а друга - на захід від міста (Лотоикий, 1970: 272-273). 
У смузі 5 А ввійшла в прорив КМГ (командир - генераллейтенант М.С. Осликовський), наступного дня ввірвалася в Сєнно і перерізала залізницю Орша-Лепель. Згідно з рішенням Маршала А. М. Василевського вранці 25 червня для розвитку наступу на богушевському напрямку була введена в бій 5 гв. ТА. Наприкінці другого дня, долаючи супротив противника, танкісти просунулися на 50 км, оволоділи Толочин і перерізали комунікації противника на захід від Орши. 27 червня війська 11 гв. А у взаємодії з 2 гв. тк і 31 А звільнили Оршу.

На інших ділянках фронту рухомі групи і стрілецькі частини успішно розвивали наступ по всьому фронту і до кінця 28 червня досягли р. Березіна. $1 c \kappa$ у взаємодії з $1 \mathrm{m \kappa}$ в запеклому бою захопили Лепель. Під час шестиденних боїв війська 1 ПФ і 3 БФ прорвали оборону противника на понад 200-км фронті, розгромили його угруповання в районі Вітебськ-Орша (основні сили 3 TA) і просунулися на 80 - 150 км на захід, створили умови для розвитку наступу військ 1 ПФ на Полоцьк, Свенцяни, а війська 3 БФ - на Молодечно і Мінськ 3 метою оточення i подальшого знищення 4 А вермахту (Платонов, 1958: 334).

У ході проведення операції заслуговують уваги питання взаємодії між з'єднаннями 43 А 39 А з оточення гітлерівських військ в районі Вітебська, яке є прикладом оточення ворога у найближчій оперативній глибині оборони двостороннім охопленням і знищенням протягом п'яти діб. Особливістю оточення вітебського угруповання $\epsilon$ те, що це було здійснено силами загальновійськових армій, без участі бронетанкових військ.

Наступ військ 2 БФ розпочався 23 червня одночасно 3 військами 1 ПФ і 3 БФ. У перший день Могильовської операчії війська 49 А, що завдали головний удар, прорвали оборону противника на 12-км ділянці на захід від Халюпи, Каменка і просунулися на 5-8 км. Використовуючи успіх 49 А ударне угруповання фронту протягом двох діб форсувало р. Бася і до кінця 25 червня вийшло на р. Реста, просунувшись на 25 км, а 50 А у взаємодії з 49 А оволоділа Чауси і досягла р. Реста, створивши загрозу флангам і тилу противника, що знаходилися на південь від Орши. В ніч на 26 червня німецьке командування розпочало відведення своїх військ. Війська $33 \mathrm{~A}$, переслідуючи противника, що відступав просунулися в глибину на 30 км і вийшли на р. Буся. 
До кінця 28 червня війська фронту, форсувавши Дніпро, оволоділи Могильовом і вийшли на лінію Слободка, Головчин, В'юн і створили умови для розвитку наступу на мінському напрямку (Платонов, 1958: 335-336).

Успішно розвивався наступ і військ правого крила 1 БФ (3 A, 48 A, 65 A, 28 A, 16 ПА, КМГ (1 мк і 4 гв. кк), 9 гв. $m \kappa$ і 1 гв. $m \kappa$. Всього близько 1300 танків). На бобруйському напрямку оборонялися 9 А і дві дивізії 4 А групи армій «Центр» (Всього 130 тис. чол., понад 350 танків і штурмових гармат, близько 2500 гармат і мінометів).

Перед початком Бобруйської операщиї, напередодні загального наступу, передовими батальйонами була проведена розвідка боєм. До кінця 23 червня передові батальйони розкрили систему оборони німців. Операцію здійснювали війська правого крила 1 БФ.

Замислом операції передбачалося завдати по противнику два удари за напрямками, що сходяться: один - 3 району на північ від Рогачова, другий - 3 району південно-західніше Парачі у напрямку на Бобруйськ з метою оточення головних сил 9 А, у подальшому передбачалося наступати на Пуховичі, Слуцьк (До складу північного (рогачовського) угруповання входили $3 \mathrm{~A}$, 48 А і $9 m \kappa$ (рухома група 3 А), південного (паричського) - 65 А, 28 А, КМГ і 1 гв. тк (рухома група 65 А) (Дайнес, 2009: 484).

У ніч перед наступом була проведена попередня авіаційна підготовка за участю до 500 бомбардувальників авіації дальньої дії і 16 ПА. В ході 125-хвилинної артилерійської підготовки піхота, танки і САУ наблизилися до переднього краю і після потужного останнього вогневого нальоту перейшли в атаку (Ротмистров, 1963: 378-379). 3'єднання 65 А і 28 А у взаємодії 3 1 гв. $m \kappa$ у перший же день операції прорвали першу, а на окремих ділянках i другу смугу оборони противника. Введення в бій танкового корпусу було здійснено в той момент, коли піхота наблизилася до третьої смуги оборони противника, а танків БПП не вистачало. Своєчасне нарощування зусиль дозволило виконати поставлене завдання високими темпами (Лотоияий, 1970: 275). 1 гв. $m \kappa$ увійшовши в прорив, у перший же день углибив його вбік Бобруйська на 20 км. Це дало можливість зранку наступного дня ввести в бій КМГ (4 гв. кк $i$ 1 мк. Під час операчіï був посилений 9 тк) (командир - генерал-лейтенант I.А. Плієв). 1 гв. $m \kappa$ і КМГ 25 червня збиваючи частини противника, що відступав, швидко просувалися вперед (Жуков, 1983: 138). 
В ніч на 26 червня армії північного угруповання прорвали другу смугу оборони противника, і був введений у бій $9 \mathrm{m \kappa}$ (ЦАМО РФ, ф. 38. оп. 11360. спр. 498, арк 73). 9 тк прорвався в тили ворожого угруповання, вийшов на східний берег Березіни (захопивши єдиний міст через річку) в районі Титовки, а до ранку 27 липня перехопив всі шосе і переправи північно-східніше Бобруйська (Рокоссовский,1988: 259). Його частини за 10 год. просунулися на 30 км і вийшли до Бобруйська.

КМГ фронту з ходу прорвала другу смугу оборони і розвивала наступ у глибину, прикриваючи головні сили фронту, що діяли в районі Бобруйська, від ударів противника із заходу. 27 червня 1 мк оволодів Глушою, перерізавши залізницю Бобруйськ-Слуцьк i розвивав наступ на Слуцьк. 1 гв. $к к ~ 27$ червня передовими бригадами вийшов на Березіна в районі Шатково, завершивши оточення 40-тисячного бобруйського угруповання німців (в оточення попало шість дивізій 35-го армійського корпусу ( $а \kappa)$ і $41 \mathrm{m \kappa}$ ) (Дайнес, 2009: 485).

Ліквідацію оточеного угруповання противника було покладено на 48 А і частину сил $65 \mathrm{~A}$, а рухомі війська спільно 3 головними силами фронту отримали завдання продовжувати наступ у напрямку Осиповичі, Пуховичі на Слуцьк.

Спроби вирватися 3 оточення в районі Бобруйська німецьких військ були безуспішними. До ранку 29 червня м. Бобруйськ було повністю очищене від ворожих військ.

У своїх спогадах відмічає зростаючу досконалість військ ЧА щодо ведення наступу командувач 4 А вермахту Курт фон Тіппельскірх. Після завершення піхотою прориву в нього негайно вводилися великі танкові сили. Уже в перші дні наступу на багатьох ділянках виникала критична обстановка, а резервів було мало. Противник блискавично домагався великих успіхів, а виправити становище було вже неможливо (Типпельскирх, 1999: 597-598).

Таким чином, війська 1 БФ, прорвавши оборону противника на 200-км фронті, оточили і знищили його бобруйське угруповання i просунулися на глибину до 110 км. Характерними особливостями операції $є$ масоване застосування авіації фронту щодо знищення оточеного угруповання противника і підтримка піхоти й танків новим методом - подвійним вогневим валом. 
В обстановці, що склалася, Ставка ВГК поставила завдання 1, 2 і 3 БФ (Директиви Ставки ВГК № 220123 і № 2220124 від 28.07 .1944 р.) на оточення і знищення мінського угруповання противника (Русский архив, 1999: 100).

Особливістю Мінської наступальної операщії є те, що вона була організована під час завершення попередніх операцій i розпочиналася без паузи, а відразу після розгрому великих угруповань ворога на флангах і в центрі білоруського виступу. Операція характерна і тим, що переросла 3 окремих фронтових операцій в єдину операцію групи фронтів, яка була проведена 3 метою оточення i розгрому крупного угруповання військ вермахту під час іiї переслідування (Ротмистров, 1963: 383).

Війська 1 ПФ отримали завдання розвивати наступ на полоцькому i свенцянському напрямках, оволодіти Полоцьком i Глибоке та надійно забезпечити 3 півночі наступ військ ЧА на мінському напрямку.

Командувач 3 БФ, отримавши завдання від Ставки ВГК, наказав рухомим військам і авіації фронту в оперативній взаємодії 3 1 БФ стрімко розвивати наступ на Мінськ і відрізати шляхи відступу противника на захід. КМГ потрібно було зайняти Молодечно. Командувач 5 гв. ТА отримав завдання, форсувати Березину, оволодіти районом Борисова, в подальшому розвивати наступ у смузі автостради і до кінця дня 2 липня опанувати Мінськом. На війська 5 А і 39 А покладалося завдання 3 прикриття правого крила 3 БФ. Особлива увага зверталася на досягнення високих темпів наступу, щоб не дати можливості 4 A противника вийти на схід від Мінська 3 підготовлюваного оточення (Дайнес, 2010: 599-600).

29 червня війська 3 БФ перейшли в наступ. На правому крилі фронту КМГ (3 гв. кк і 2 гв. $п к$ ) (командир - генерал-лейтенант М. С. Осліковський), форсувавши Березину, продовжували наступати на Плещеніци. На наступний день головні сили фронту вийшли до Березини. 3' єднання 5 ТА (до початку операції в армії нараховувалося танків і САУ 434 од.: Т-34 - 204, ИС-122 - 22, M4-А2 - 63, МК-9 - 38, ИСУ-152 - 23, СУ-85 - 42, СУ-76 - 42) (ЦАМО РФ, ф. 332. on. 4948. спр. 189, арк. 6) і передові загони 11 гв. A і 31 А підійшли до Борисова. Успішно форсувавши Березину i, не втручаючись у затяжні бої, обходячи вузли опору на проміжних рубежах, просувалися вперед. Головні сили 1 БФ розвивали наступ на Барановичі. 
Генерал армії К.К. Рокоссовський у своїх спогадах високо оцінює військове мистецтво рухомих з'єднань 3 оточення мінського угруповання ворога. 2 липня сильним ударом в центрі 1 гв. $m \kappa$ прорвав оборону 12 mд німців і спільно 3 піхотою $82 c \partial$ опанував районом Пуховичі, а КМГ (командир - генерал-лейтенант I.А Плієв) рвалася на Луцьк і на світанку 2 липня перерізала комунікації мінському угрупованню на Барановичі, Дунінець. $9 m \kappa$ посланий в обхід Мінська 3 півдня, опанував вузлом доріг у Любяча. А в цей же день танкові частини 3 БФ, оволоділи Смолевичами, просунулися до Мінська з північного сходу. Так було завершено оточення 4 А противника, що знаходилася на схід від білоруської столиці (Рокоссовский, 1988: 263).

2 липня 0 3-й год. 4 гв. тбр (командир - підполковник О. А. Лосик), 2 гв. відступав, більше ніж на 100 км, увірвалася на вулиці Мінська, а з'єднання 5 гв. ТА (станом на 1.07.1944 р. в 5 гв. ТА налічувалося 307 танків в строю і 24 в ремонті) (ЦАМО РФ, ф. 241, on. 2628, cnp. 48, арк. 350) вийшли на північну околицю міста. За день бою 3 гв. $m \kappa$ і $29 m \kappa$ втратили 14 танків, знищили 26 танків противника (ЦАМО РФ, ф. 332. ол. 4948. спр. 189, арк. 25-26). Стрілецькі частини $11 \mathrm{~A}$ i $31 \mathrm{~A}$, що підійшли незабаром, розпочали зачищати квартал за кварталом від ворога. 1 гв. ніч на 3 липня, обійшовши Мінськ 3 півдня, вийшов на південносхідну частину міста і з'єднався 3 частинами 1 БФ. Кільце навколо сил 4 А і окремих частин 9 А противника замкнулося, в оточення попало 105 тис. чол. Мінськ на кінець дня був повністю очищений від гітлерівців (Дайнес, 2010: 601).

Завдання щодо розгрому оточеного угруповання противника i розвитку наступу були визначені Директивами Ставки ВГК №o 220126, 220127, 220128, 220129, 220130, 220131 від 4.07.1944 p. (Русский архив, 1999: 102-104). Виконуючи отримане завдання, війська 2 БФ (33 А, частиною сил 50 А і 49 А) у взаємодії 3 авіацією і партизанами 34 по 11 липня розчленували і повністю ліквідували оточене угруповання противника (Лотоцкий, 1970: 279).

В ході Мінської операції оточення крупного угруповання військ вермахту завершувалося під час переслідування і в оперативній глибині. Оточення військ противника здійснювалося у взаємодії трьох фронтів. А про дії військ П. А. Ротмістрова у 
своїх мемуарах А. М. Василевський відзивається прохолодно: «5 гв. ТА, завжди блискуче проявляла себе, в даному випадку діяла гірше, ніж раніше» (Василевський, 1978: 420).

Під час ліквідації противника в оточенні, головні сили фронтів продовжували наступ. На відміну від попередніх операцій, у наступі вперше були застосовані дивізійні, корпусні і армійські передові загони (до їх складу входили: до батальйону піхоти на автомобілях, артилерійський дивізіон $(a \partial \mu), 6-10$ танків і САУ, 1-2 протитанкові батареї та необхідна кількість саперів і розвідників), які забезпечували головним силам дивізій (корпусів) наступати в колонах, що підвищувало темпи їх просування, а розгорталися лише тоді, коли противник чинив сильний супротив (Ротмистров, 1963: 387-388).

Чітка організація та взаємодія трьох фронтів дозволили організувати прорив оборони та переслідування військ противника. У Мінській операції війська ЧА на зовнішньому фронті не переходили до оборони на певному, досягнутому рубежі, а без оперативної паузи продовжували розвивати наступ вглибині.

Війська 1 ПФ після завершення спільно з 3 БФ, ВітебськоОршанської операції приступили до проведення Полоцької операціï. Військам генерала армії І. Х. Баграмяна протистояли війська 16 А групи армій «Північ» (командувач - генералполковник Г. Ліндеман) і частина сил 3 ТА групи армій «Центр» (командувач - генерал-фельмаршал В. Модель). Як згадує командувач фронтом, 329 червня по 4 липня найбільш запеклі бої розгорілися за Полоцьк, німецьке командування робило відчайдушні спроби утримати місто. На підступах до Полоцька була підготовлена оборонна смуга під грізним найменуванням «Тигр», а саме місто також було ретельно підготовлене до кругової оборони (Баграмян, 1977: 333).

Замисел операції передбачав ударом у напрямках, що сходяться, оточити і розгромити полоцьке угруповання противника.

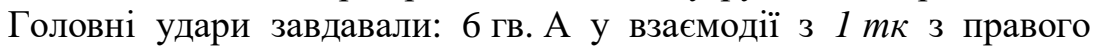
флангу фронту в напрямку на Полоцьк, 4 УА 3 лівого флангу в напрямку на Котляни-Полоцьк (Операщия «Багратион», 2004: 139).

Використовуючи успіх 4 УА і 6 гв. А $1 m \kappa$, вийшли в оперативний простір $\mathrm{i}$, завдавши стрімкого удару, 29 червня оволодів Ушачи. А наступного дня 150 тбр 1 mк несподівано для противника увірвалася на вулиці Дисни. Скориставшись поспішним 
відступом противника, слідом за ним захопленим поромом частина підрозділів переправилася на правий берег i захопила невеликий плацдарм. 1 червня війська 6 гв. А і 4 УА перейшли в наступ і до ранку 4 липня звільнили Полоцьк (Дайнес, 2009, p. 488-489).

Успішне просування військ 1 ПФ на полоцькому і свенцянському напрямках надійно забезпечило 3 півночі наступ головного стратегічного угруповання військ ЧА в Білорусії. На цьому завершився перший етап Білоруської операції.

Другий етап операції для 1 ПФ, 3 Бф і 2 БФ розпочався 5 липня військ 1 ПФ (6 гв. А, 43 А, 39 А, 2 гв. А, 51 А) 3 проведення Шяуляйської наступальної операції. Отримавши завдання та розвиваючи наступ, завдати головний удар у напрямку Свенцяни, Каунас. Найближче завдання - не пізніше 10-12 липня вийти на рубіж Двінськ, Нові Свенцяни, Підбродзе. В подальшому, надійно забезпечуючи себе 3 півночі, наступати на Каунас i частиною сил на Панявежис, Шяуляй (Русский архив, 1999: 103).

Під натиском військ 1 ПФ в обороні противника на шуляйському напрямку утворився значний пролом. Командувач фронтом 20 липня ввів у бій 51 А і 2 гв. А, які отримали завдання завдати головний удар на Шяуляй. А 26 липня для подолання зростаючого опору противника генерал армії I.X. Баграмян ввів у бій західніше Панявежиса 3 гв. мк. За день корпус просунувся більше ніж на 90 км, а його частини вийшли на околиці Шяуляя. 27 липня війська 51 А 33 гв. мк, обійшовши місто 3 північного заходу і південного заходу, оволоділи Шяуляєм. Цього ж дня командувач 1 ПФ отримав завдання повернути головні сили фронту на Ригу, а лівим крилом наступати на Мемель (Русский архив, 1999: 117).

3 гв. мк у швидкому темпі 28 липня подолавши 80 км вийшов до Слгави, де зав'язалися запеклі бої. Для обходу міста командир корпусу виділив 8 гв. мбр, яка, використовуючи проміжки в обороні противника, 31 липня захопила Тукумс, а передовим загоном підійшла до Ризького заливу, а 51 А і головні сили 3 гв. мк захопили Слгаву. Війська правого флангу 1 ПФ вийшли на рубіж півд. Лівани, р. Мемеле, а лівого - на рубіж Куршенай, Кедайняй і перейшли до оборони (Дайнес, 2009, p. 496).

Під час операції війська 1 ПФ просунулися на 100 - 400 км. Відрізавши групі армій «Північ» шляхи відступу у Східну Прусію, змусили гітлерівське командування перекинути значні сили для відновлення своїх комунікацій. 
Війська 3 БФ приступили до проведення Вільнюської наступальної операщії. Генерал армії І.Д. Черняховський отримав завдання: 3 БФ (5 A, 11 гв. А, 31 А, 33 А, 5 гв. ТА, 3 гв. мк, 2 гв. $m \kappa, 3$ гв. кк) розвивати наступ, завдаючи головний удар у загальному напрямку на Молодечно, Вільно.

Найближче завдання військ фронту - не пізніш 10-12 липня опанувати Вільно (нині - Вільнюс) і Лідою. Надалі вийти на p. Німан і захопити плацдарми на його західному березі (Русский архив, 1999: 101).

Характерними є дії військ фронту щодо звільнення Вільнюса і захоплення плацдармів на р. Німан.

Щоб упередити противника, командувач фронтом скерував 5 гв. ТА на Вільнюс. Одночасно 3 гв. мк зламавши супротив двох німецьких дивізій, зайняв залізничну станцію Сморгонь. 5 липня частина сил 11 гв. А спільно із з'єднаннями КМГ (командир генерал-лейтенант М.С. Осликовський) і 25 тбр (командир підполковник І.П. Міщенко) $29 m \kappa 5$ гв. ТА зайняли крупний залізничний вузол і важливий опорний пункт оборони противника на вільнюському напрямку - м. Молодечно.

В ніч на 7 липня з'єднання 3 гв. мк форсували р. Вілія, увірвалися на південну і східну частину Вільнюса. На кінець дня до південно-східної околиці Вільнюса підійшов 29 жк (командир генерал-майор т/в Є.І. Фоміних). Зранку наступного дня в бій вступили частини 3 гв. $m \kappa$ (командир - генерал-майор т/в I.А. Вовченко), які із запеклими боями дуже повільно просувалися до центру міста. 13 липня Вільнюс було звільнено (Платонов, 1958: 349).

До 20 липня війська фронту завершили операцію і просунулися на глибину 210 км. Були створені сприятливі умови для наступу до Східної Прусії. Особливостями операції було застосування для захоплення тактичних плацдармів рухомих груп i передових загонів загальновійськових армій і з'єднань, створення внутрішнього i зовнішнього фронтів оточення рухомими військами. До недоліків слід віднести втягування рухомих груп у бої за великі населені пункти (5 гв. ТА в боях за Вільнюс).

Війська 2 БФ (3 A, 49 А, 50 А, 4 ПА) провели Білостоцььку операцію. 27 липня звільнили Білосток і вийшли на підступи до кордону Східної Прусії. Війська фронту просунулися в глибину на 300 км, знищили чотири німецькі дивізії, а також завдали 
великих втрат шести дивізіям і двом бригадам, зірвали план противника завдати удар по правому флангу військ 1 БФ (Кривизюк, 2021: $78-83$ ).

3 виходом військ правого крила 1 БФ на підступи до Бреста були створені умови для переходу в наступ i військ лівого флангу. Замислом Люблін-Берестейської наступальної операції передбачалося у завданні потужних ударів в обхід Берестейського укріпрайону (УР) 3 півночі та півдня розгромити берестейське та люблінське угруповання німецьких військ, і розвиваючи наступ на варшавському напрямку, вийти на широкому фронті до p. Вісла. Основні зусилля командувач фронтом зосередив на лівому фланзі. Для розвитку успіху долучалися 2 ТА (командувач генерал-лейтенант C.I. Богданов, 323 липня по 20 листопада 1944 p. - генерал-майор O.I. Радзієвський), 7 гв. кк (командир генерал-майор (з 26.07.1944 - генерал-лейтенант) М.П. Константинов) i 2 гв. кк (командир - генерал-майор В.В. Крюков). 11 тк входив до складу 8 гв. А (Платонов, 1958: 354).

Головний удар завдали 47 A, 8 гв. А і 69 A із завданням прорвати оборону противника на захід від Ковеля, забезпечити введення в бій рухомих військ і у взаємодії з ними розвивати наступ на Седльце і Люблін. Після форсування Зах. Бугу 8 гв. А та 2 ТА (810 танків і САУ) (ЦАМО РФ, ф. 307, on. 4148, cnp. 1, арк. 170) повинні були розвивати наступ на Лукув, Седльце (Сідлець), а 69 А і 1-ша польська армія - на Люблін, Гміна Міхув. На флангах 2 ТА передбачалося використовувати 2 гв. кк і 7 гв. кк. Війська 47 А повинні були наступати на Бяла Подляска i не допустити відходу до Варшави військ противника, що діяли на схід від кордону Седльце, Лукув. 70 А завдала удар на Брест 3 півдня (Дайнес, 2010: 331).

Праве крило фронту (48 A, 65 A, 28 A, 61 A, $9 m \kappa, 1$ гв. $m \kappa$, 1 мк, 4 гв. кк) отримало завдання завдати удар напрямку на Барановичі, Брест. Військам правого крила належало опанувати районом Барановичі, Лунинець і не пізніше 10-12 липня вийти на рубіж Слонім, р. Шара, Пінськ. Надалі опанувати Брестом і вийти на p. Зах. Буг, захопивши плацдарми на його лівому березі (Русский архив, 1999: 102).

Наступ розпочався вранці 18 липня. Ставка ВГК вимагала не пізніше 26-27 липня оволодіти м. Люблін, для чого в першу чергу використовувати 2 ТА і 7 гв. кк (Русский архив, 1999: 113). 
Створена КМГ (командир - генерал-лейтенант В.В. Крюков), розвиваючи наступ на північний захід, 23 липня опанувала містами Парчев і Радзинь. У ніч на 25 липня вона зав'язала бій за Седльце, після запеклих боїв місто 31 липня було зайняте спільними зусиллями піхоти, кавалерії і танків (Дайнес, 2009: 500).

Противник спішно перекидав до Варшави 3 півдня 19 mд, танкові дивізії СС «Мертва голова» і «Вікінг», дивізію «Герман Герінг», що прибула 3 італійського фронту i ряд піхотних з'єднань німецької 2 А. Одночасно активізувала свою діяльність ворожа авіація. У той час як противник у районі Варшави значно посилився. Противник виявив загрозу з півдня крупного танкового угруповання ЧА проти Праги і Варшави, приймає термінові заходи 3 організації оборони Варшавського УР, посилює дану ділянку новими частинами, в основному танковими (Дайнес, 2010: 335).

Війська 2 ТА 1 серпня наштовхнувшись на Варшавський вузол оборони противника, перейшли до оборони на рубежі Радзімін, Струга, Оссув, Окунєв, Закрент, (викл) Мендзилесе, (викл) Збитки (ЦАМО РФ, ф.307, on. 4148, спр. 1, арк. 189-190).

4 серпня командувач 1 БФ наказав: «2 ТА здати ділянки оборони, що займали $47 \mathrm{~A} \mathrm{і} 2$ гв. кк. Армію зосередити в районі Мінськ Мазовецький. Надалі бути готовою до наступу в північному напрямку на Станіславів, Лохув» (ЦАМО РФ, ф. 307, on. 4148, спр. 1, арк. 195).

В ході операції широко застосовувалися маневр рухомими з'єднаннями (об'єднаннями), поєднання різних способів розгрому ворожих угруповань - брестського шляхом оточення і подальшого знищення, а люблінського - завданням глибоких розсікаючих ударів, вміло здійснювалося форсування 3 ходу великих водних перешкод із захопленням і розширенням плацдармів (Кривизюк, 2021: 78-83).

Війська 3 БФ без паузи приступили до проведення Каунаської наступальної операції. Завдання фронту визначила Ставка ВГК. Замислом на операцію передбачалося розвивати наступ силами 39 A i 3 А із завданням не пізніше 1-2 серпня 1944 р. ударом 3 півночі і півдня опанувати Каунасом. Надалі усіма силами фронту наступати до кордонів Східної Пруссії і не пізніше 10 серпня оволодіти рубежем Россієни, Юрбург, Ейдкуннен, Сувалки, де міцно закріпитися для підготовки до вторгнення в Східну Пруссію, в загальному напрямку Гумбінен, Інстербург, Прейсиш-Айлау (Русский архив, 1999: 117). 
Виконуючи рішення Ставки ВГК генерал армії І.Д. Черняховський 28 липня прийняв рішення силами 5 А звільнити Каунас. Північніше завдавала удар 39 А армія у взаємодії 35 гв. ТА, а південніше - 33 А.

Після 40-хв артилерійської підготовки війська 3 БФ перейшли в наступ (Дайнес, 2010: 606).

В ніч на 30 липня командувач фронтом перекинув 2 гв. $m \kappa ~ з$ 11 гв. А, що наступала на напрямку головного удару, у смугу 33 А. Допоміжний напрямок неочікувано для противника став головним. Частини 11 гв. А і 2 гв. $m \kappa$ за день бою прорвали оборону противника на глибину до 40 км. Танкісти, вийшовши в район Казлу Руда, Пильвишкіс, відрізали шляхи відступу німецькому каунаському угрупованню. Маневр 2 гв. $m \kappa$ переломив хід операції. Війська 5 А 1 серпня повністю захопили Каунас (Дайнес, 2009: 494). А $19 c \kappa 33$ А опанував 31 липня містом i залізничною станцією Мариямполе (Капсукас) (Бешанов, 2005: 468).

5 гв. ТА, продовжуючи наступ силами двох танкових і двох мотострілецьких бригад до 15 год., оволоділа м. Ейрагола (ЦАМО РФ, ф. 332, on. 4948, спр. 192, арк. 7).

Противник (частинами $212 n d, 256$ бойової групи, групи «Ланге», 95 і 197 бойовими групами, 69 пд за підтримки танків 7 mд і 6 mд, артилерії РГК 81 адн.) протягом 5 серпня чинив запеклий опір наступу військам 5 гв. ТА в районі зах. Ейрагола. Групами 10-15 танків за підтримки артилерії неодноразово переходили в контратаки. Артилерію, танки і САУ противник застосовував на танкодоступних напрямках виключно із засад, періодично контратакував танками 3 півдня у лівий фланг армії (ЦАМО РФ, ф.332, оn. 4948, спр. 192, арк. 9-10).

3 гв. $m \kappa$, долаючи завзятий вогневий опір танків САУ противника, 15 серпня оволодів Калнуї, відбивши три контратаки противника, і до кінця дня вів бій на рубежі: зах. Довойно, зах. ок. Калнуї.

Видатний англійський військовий теоретик визнає, що «До середини серпня становище німців стало до крайності відчайдушним» (Фуллер, 1956: 409).

В результаті Каунаської операції війська фронту вийшли до кордонів Східної Пруссії і створили умови для розгрому противника на його території.

Втрати військ ЧА за Білоруську операцію склали 765815 чол., з яких 178507 - безповоротні (Кривошеев, 1993: 203). 
Успіх, досягнутий військами трьох Білоруських фронтів i 1 ПФ на другому етапі операції, вдало використали війська 2 ПФ, 3 ПФ, 1 УФ і Ленінградського фронту, які діяли згідно з планом Ставки ВГК і послідовно переходили в наступ на своїх напрямках, чим збільшували розмах стратегічного наступу (Кривизюк, 2021: 78-83).

Висновки. 3 виходом військ Червоної Армії до кордонів Східної Прусії і до Вісли були створені сприятливі умови для проведення нових крупних операцій на варшавсько-берлінському напрямку.

Білоруська стратегічна наступальна операція збагатила теорію і практику оточення та знищення крупних угруповань противника. Оточення досягалося як групою фронтів, так і силами одного фронту. Оточення і знищення противника відбувалося як єдиний процес. Група армій «Центр» під час оточення дробилася i знищувалася частинами, а зовнішній фронт оточення створювався не оборонними діями, а наступальними. Новим в оперативному мистецтві дій військ Червоної Армії було те, що оточення 105тисячного угруповання військ вермахту було досягнуто під час паралельного і фронтального переслідування на глибині 200 250 км від переднього краю. Оточення і знищення противника здійснювалося одночасно.

Важливою умовою в досягненні стрімких темпів наступу було високе мистецтво командування і штабів всіх рівнів в управлінні військами та висока відповідальність і фаховість під час виконання бойових завдань.

Одним із найважливіших умов успішного проведення операції було всебічне забезпечення, підготовка в центрі і на місцях.

Основною особливістю фронтових наступальних операцій, що здійснювалися послідовно у глибину у рамках стратегічної операції, відігравало те, що вони зазвичай готувалися під час попередніх операцій, без будь-яких пауз.

Важливе значення у вирішенні завдань щодо нарощування зусиль фронтів під час стратегічної операції відігравали резерви Ставки ВГК.

Однією з умов, що забезпечила успіх стратегічної операції в цілому, була добре відпрацьована взаємодія всіх, хто долучався до операції.

Значної уваги заслуговують дії командування Червоної Армії щодо застосування рухомих з'єднань під час стрімкого маневру 2 ТА $з$ району Демблін уздовж правого берега Вісли на Прагу, 
3 гв. кк 3 району Молодечно на Гродно. Незважаючи на складні умови лісисто-болотистої місцевості, в окремі дні темп просування рухомих груп досягав 50-70 км на добу.

Повчальним щодо використання бронетанкових і механізованих військ $є$ їх різноманітне застосування. Особливо ефективно вони діяли у складі рухомих груп армій і фронтів, вони своїми стрімкими діями надавали операції швидкоплинний та маневрений характер і використовувалися після прориву тактичної зони оборони противника, що дозволило зберегти ударну силу для розвитку успіху в оперативній глибині, що зумовлювало до збільшення розмаху фронтових і армійських наступальних операцій та досягнення в них рішучих результатів.

Бронетанкові і механізовані війська в операції застосовувалися масовано, на напрямку головних ударів фронтів долучали до 70-90\% танків і САУ.

Операція характерна участю в ній значної кількості артилерії. Найважливішим принципом іï застосування було рішуче масування на напрямках головних ударів.

Під час операції застосовувалися крупні Військово-Повітряні Сили - п'ять повітряних армій фронтів, авіація дальньої дії i винищувальна авіація Протиповітряної оборони країни. Була досягнута непереривність авіаційної підтримки сухопутних військ на всю глибину операції і рішучим іiі масуванням на найважливіших напрямках. Під час операції подальший розвиток отримав досвід організації тісної взаємодії фронтової та авіації дальньої дії, а також досвід організації взаємодії з сухопутними військами.

Для відбиття наступу військ ЧА в Білорусії німецьке ВГК вимушене було вилучити зі складу групи армій «Північна Україна» шість дивізій (з них три танкові), а зі складу групи армій «Південна Україна» дванадцять дивізій (з яких шість танкових і одна моторизована), що сприяло успішному проведенню Львівсько-Сандомирської і Яссько-Кишинівської стратегічних наступальних операцій.

\section{Використані посилання}

Баграмян И. (1977). Так или мы к победе. Москва: Воениздат, 608 с.

Бешанов В. (2005). Десять сталинских ударов. Москва: АСТ, Мн.: Харвест. 768 с.

Василевский А. (1978). Дело всей жизни. Издание третье. Москва: Политиздат. $552 \mathrm{c.}$

Воробьев Ф.Д., Кравцов В.М. (1953). Победы Советских Вооруженных Сил в Великой Отечественной войне. 1941-1945 (Краткий очерк). Москва: Воениздат. 433 с. 
Дайнес В. (2009). Бронетанковые войска Красной Армии. Москва: Яуза: Эксмо. 640 с.

Дайнес В. (2010). Советские танковые армии в бою. Москва.: Яуза: Эксмо, 800 c.

Жилин, П. А. (1988). Боевой состав Советской Армиии. Часть IV (Январь декабрь 1944 г.). Москва.: Воениздат. 376 с.

Жилин, П. А. (1986). История военного искусства. Москва.: Воениздат. 446 с.

Жуков Г. К. (1983). Воспоминания и размышиения. Т. 3. Москва: Издательство Агентства печати Новости. 352 с.

Исаев А. Операция «Багратион». «Сталинский блицккиг» в Белоруссии. (2014) Москва: Яуза. 448 с.

Кривизюк Л. П. (2010). Застосування танкових об'єднань у ЛьвівськоСандомирській операції. Військово-науковий вісник. Випуск 13. Львів: АСВ, С. 49-63.

Кривизюк Л. П. (2021). Операція «Багратіон» (23 червня-29 серпня 1944 року): успіхи і прорахунки щодо застосування рухомих військ. The driving force of science and trends in its development: collection of scientific papers «SCIENTIA» with Proceedings of the I International Scientific and Theoretical Conference (Vol. 5), January 29. Coventry, United Kingdom: European Scientific Platform.

Кривошеев Г. (1993). Гриф секретности снят: Потери Вооруженных Сил СССР в войнах, боевых действиях и военных конфликтах: Статистическое исследование. Москва.: Воениздат. 415 с.

Лотоцкий С. С. (1970). История войн и военного искусства. Учебник для высиих военных учебных заведений. Москва: Воениздат. 560 с.

Операция «Багратион». Освобождение Белоруссии. (2004) Москва: Олмапресс. 488 с.

Платонов С. П. (1958). Операции Советских Вооруженных Сил в Великой Отечественной войне 1941-1945 г2. Т. 3. Москва. 840 с.

Поспелов П. Н. (1962). История Великой Отечественной войны Советского Союза 1941-1945 г2. Т. 4. Москва.: Воениздат. 726 с.

Радзиевский А.И. (1977). Танковый удар: танковая армия в наступательной операции фронта по опьту Великой Отечественной войны. Москва.: Воениздат, $290 \mathrm{c.}$

Рокоссовский К. К. (1988). Солдатский долг. Москва: Воениздат. 367 с

Ротмистров П. А. (ред.) (1963). История военного искусства. Т. 2. Москва: Воениздат. $720 \mathrm{c.}$

Ротмистров П. А. (1972). Время и танки. Москва: Воениздат. 336 с.

Русский архив: (1999). Великая Отечественная: Ставка ВГК: Документы и материаль: : 1944-1945. Т. 16(5-4). Москва: ТЕРРА, 368 с.

Семиряга М. И. (ред.) (1978). История Второй мировой войны 1939-1945 ге. T. 9. Москва.: Воениздат. 574 с.

Советские танковые войска 1941-1945. Военно-исторический очерк. (1973). Москва:: Воениздат. 334 с.

Строков А. А. (ред.) (1966). История военного искусства. Москва: Воениздат. $656 \mathrm{c.}$

Тельпуховский Б. С. (1959). Великая Отечественная война Советского Союза. 1941-1945. Краткий очерк. Москва.: Государственное издательство политической литературы. 577 с.

Типпельскирх К. История Второй мировой войны. (1999). Москва: АСТ. 796 с.

Фуллер Дж. (1956). Вторая мировая война 1939-1945 г2. Стратегический и тактический обзор. Москва: Иностранная литер. 550 с. 
Хаупт В. (2006). Сражение группь армий «Центр». Взгляд офицера вермахта. Москва: Яуза, Эксмо. 347 с.

Штеменко С. (1975). Генеральный штаб в годы войны. Книга 1. Москва: Воениздат. 486 с.

Центральный архив Министерства обороны Российской федерации (далі ЦАМО РФ).

\section{References}

Bagramyan I. (1977). Our path to victory. Moscow: Military Publishing, 608 p. Beshanov V. (2005). Stalin's ten shocks. Moscow: AST, Minsk: Harvest. 768 p. Central archive of the Ministry of Defense of the Russian Federation.

Daines V. (2010). Soviet tank armies in battle. Moscow.: Yauza: Eksmo, 800 p.

Daynes V. (2009). Armored troops of the Red Army. Moscow: Yauza: Eksmo. 640 p.

Fuller J. (1956). The Second World War 1939-1945. A Strategical and Tactical History. Moskva.: Foreign literature. 350 p.

Haupt W. (2006). Battle of Army Group "Center". View of the Wehrmacht officer. Moscow: Yauza, Eksmo. 347 p.

Isaev A. (2014). Operation "Bagration". "Stalin's Blitzkrieg" in Belarus. Moscow: Yauza. 448 p.

Krivosheev G. (1993). The classification is removed: Losses of the Armed Forces of the USSR in wars, hostilities and military conflicts: Statistical research. Moscow: Voenizdat. 415 p.

Kryvyzyuk L. P. (2010) Employment of tank formations in the Lviv-Sandomierz operation. Military-scientific bulletin. Iss. 13. Lviv: pp. 49-63.

Kryvyzyuk L. P. (2021). Operation "Bagration” (June 23-August 29, 1944): successes and failures in the use of mobile troops. The driving force of science and trends in its development: collection of scientific papers "SCIENTIA" with Proceedings of the I International Scientific and Theoretical Conference (Vol. 5), January 29. Coventry, United Kingdom: European Scientific Platform.

Lototskii S. S. (1970). History of wars and military art. Textbook for higher military educational institutions. Moscow: Military Publishing, 560 p.

Operation "Bagration”. Liberation of Belarus. (2004) Moscow: Olma-press. 488 p.

Platonov S. P. (1958). Operations of the Soviet Armed Forces in the Great Patriotic War of 1941-1945. Vol. 3. Moscow. 840 p.

Pospelov P. N. (1962). History of the Great Patriotic War of the Soviet Union 1941-1945. Vol. 4. Moskva: Voenizdat. 726 p.

Radzievskii A. I (1977). Tank assault: the tank forces in front offensive operation based on the experience of the Great Patriotic War. Moscow: Military Publishing, $290 \mathrm{p}$.

Rokossovskiy K. K. (1988). Soldier's duty. Moscow: Voenizdat. 367 p.

Rotmistrov P. A. (1963). History of military art. Vol. 2. Moscow: Voenizdat. 720 p.

Rotmistrov P.A. (1972). Time and tanks. Moscow: Military Publishing. 336 p.

Russian archive: (1999). The Great Patriotic War: Supreme Command Headquarters: Documents and materials: 1944-1945. Vol. 16 (5-4). Moscow: TERRA, 368 p.

Semiryaga M. I. (1978). History of World War II 1939-1945. Vol. 9. Moscow: Voenizdat. 574 p.

Shtemenko S. (1975). General staff during the war. Book 1. Moscow: Voenizdat. 486 p.

Soviet tank troops 1941-1945. Military history sketch. (1973). Moscow: Voenizdat. $334 \mathrm{p}$.

Strokov A. A. (1966). History of military art. Moscow: Voenizdat. 656 p. 
Telpukhovsky B. S. (1959). The Great Patriotic War of the Soviet Union. 1941-1945. Brief sketch. Moscow: State publishing house of political literature. 577 p.

Tippelskirch K. History of the Second World War 1939-1945. (1999). Moscow: AST. 796 p.

Vasilevskiy A. (1978). A matter of a lifetime. Third edition. Moscow: Politizdat. 552 p.

Vorobiov F. D., Kravtsov V. M. (1953). Victories of the Soviet Armed Forces in the Great Patriotic War. 1941-1945 (Short essay). Moscow.: Voenizdat. 433 p.

Zhilin P.A. (1986). History of military art. Moscow: Military Publishing. 446 p.

Zhilin P.A. (1988) The combat composition of the Soviet Army. Part IV (January - December 1944). Moscow: Military Publishing. 376 p.

Zhukov G. K. (1983). Memories and Reflections. Vol. 3. Moskva: Press Agency Publishing News. 352 p.

\section{Kryvyziuk L.}

BELARUSIAN STRATEGIC OFFENSIVE OPERATION (June 23-August 29, 1944): ORGANIZATION OF COORDINATION OF TROOPS OF FOUR FRONTS

Author continues with publications on the use of troops in strategic and frontline operations during World War II. A military-historical analysis of the Belarusian strategic offensive operation was carried out: the situation in Belarus after the fighting in the winter and spring of 1944; general plans of the parties for the summer-autumn campaign; plans of front commanders to conduct frontline operations and tasks for troops; issues of coordination between the troops of the fronts, general armies, mobile groups, artillery and air units during the preparation and conduct of the operation. As well conclusions were drawn.

The Belarusian strategic offensive operation enriched the theory and practice of encirclement and the destruction of large enemy groups. The encirclement was achieved both by a group of fronts and by forces of one front. The encirclement and destruction of the enemy took place as a single process. During the siege, the Army Group "Center" was crushed and destroyed in parts, and the outer front of the encirclement was created not by defensive actions but by offensive ones. What was new in the operational art of the Red Army was that the encirclement of the 105,000strong Wehrmacht group was reached during a parallel and frontal pursuit at a depth of $200-250 \mathrm{~km}$ from the front line. The encirclement and destruction of the enemy was carried out simultaneously.

An important condition for achieving a rapid pace of offensive was the high art of command and staff at all levels in the management of troops and high responsibility and professionalism in the performance of combat missions by personnel.

One of the conditions that ensured the success of the strategic operation as a whole was the well-established coordination of all those involved in the operation.

The educative side of the use of armored and mechanized troops is their various employment. They acted especially effectively as part of mobile groups of armies and fronts.

Keywords: Belarusian strategic offensive operation, General Headquarters, front, army, corps, enemy. 